\title{
SPIRITUALITAS DAN MOTIVASI MENOLONG PADA MAHASISWA
}

\author{
Henndy Ginting \\ Fakultas Psikologi Universitas Kristen Maranatha \\ email: henndyg@yahoo.com
}

\begin{abstract}
Abstrak
Penelitian ini mengkaji keterkaitan antara spiritualitas sebagai bagian yang esensial dari agama dan motif prososial sebagai dasar terbentuknya tingkah laku prososial dan altruistik. Partisipan penelitian adalah mahasiswa Sekolah Tinggi Teologi di Bandung yang berjumlah 300 orang. Teori yang digunakan adalah perspektif Hall dan Edwards yaitu self-God relationship awareness (ARG) dan quality of one's relationship with God (QRG) dan empat motif prososial (egoism, kolektivism, prinsiplism, dan altruism) dari Daniel C. Batson. Hasil penelitian menunjukkan bahwa terdapat hubungan yang kuat antara kematangan spiritual dan motif prososial dengan nilai $\mathrm{C}=0,6364$. ARG berkaitan dengan motif prososial yang didasari kolektivism ( $\mathrm{rs}=0,417)$ dan prinsiplism ( $\mathrm{rs}=$ 0,420 ). Sub dimensi unstable dan grandious lebih berkaitan dengan motif prososial yang didasari egoism dengan nilai korelasi masing-masing $r s=0,511$. Elemen empati yang berkembang pada sub dimensi realistic acceptance merupakan hal penting dalam kaitannya dengan motif prososial yang didasari oleh altruism dengan nilai korelasi pearson, $r s=0,422$.
\end{abstract}

Kata kunci: kematangan spiritual, motif prososial dan object relations.

Abstract

This study investigates the correlations between spirituality, the essential part of religion, and prosocial motive, the basis of prosocial and altruistic behavior. Participants of this study are 300 seminary students coming from various theological schools in Bandung. This study uses Hall \& Edwards theoretical perspective on Self-God Relationship Awareness (ARG), Quality of one's relationship with God (QRG), and four prosocial motives - egoism, collectivism, principleism, and altruism - of Daniel C. Batson. There is strong correlation between spiritual maturity and prosocial motives, $C=0,6364$. ARG has significantly correlation with prosocial motives collectivism $(r s=0,417)$ and principleism $(r s=0,420)$. Therefore, Unstable $(r s=0,511)$ and Grandiose $(r s=0,511)$ sub dimensions related more with prosocial motives which driven by egoism. Realistic acceptance sub dimension is significantly related with prosocial motives altruism ( $r s=$ $0,422)$.

Keywords: spiritual maturity, prosocial motives, object relations.

\section{PENDAHULUAN}

Susilo Bambang Yudhoyono, dalam pidato kenegaraan sesaat setelah dilantik sebagai Presiden Republik Indonesia yang ke-6, mengangkat isu kebersamaan, pengorbanan, dan toleransi serta saling menolong sebagai unsur penting dalam pemerintahannya sehingga kabinet- nya diberi nama Kabinet Persatuan (Kompas, 21 Oktober 2004). Secara umum perilaku menolong, berbagi, mengorbankan diri untuk orang lain, dan menjalankan norma-norma yang berhubungan dengan menolong orang lain disebut perilaku prososial (Reykowski, 1982). 
Saroglou (2002) menganggap pendekatan yang selama ini digunakan sehubungan dengan perilaku prososial, sering kali mengabaikan aspek transpersonal dan spiritual. Padahal menurutnya, kesadaran kolektif dari suatu kelompok untuk saling menolong dan tidak saling "melukai", pada dasarnya berada pada level spiritual. Hampir semua pendekatan teoritis dalam psikologi agama, menekankan pentingnya motivasi prososial, sampai kepada tingkah laku menolong tanpa mengharapkan imbalan (altruistik).

Penelitian ini mencoba menggali kemungkinan keterkaitan antara spiritualitas sebagai bagian yang esensial dari agama dan motif prososial sebagai dasar terbentuknya tingkah laku prososial dan altruistik. Menurut Daniel C. Batson (Snyder, 2002), motif prososial yang dimaksud bervariasi, mulai dari dorongan yang mengarahkan perilaku menolong orang lain untuk kepentingan diri sendiri sampai kepada tingkah laku mengorbankan diri sendiri untuk kepentingan orang lain (altruisme). Perkembangan motif prososial penting karena bila seseorang tumbuh menjadi dewasa, melalui perkembangan motif prososial, ia akan lebih mudah dalam penyesuaian diri dengan lingkungan sosialnya. Dampak yang lebih luas lagi, akan tercipta kehidupan sosial yang damai, peka pada kebutuhan orang lain, dan menjunjung tinggi kebersamaan.

Sekolah Tinggi Teologi (STT), sebagai salah satu lembaga pendidikan tinggi berkembang cukup pesat di Indonesia. Setidaknya terdapat 34 STT yang tergabung di dalam Perhimpunan Sekolah-sekolah Teologi di Indonesia (Persetia). Secara umum STT bertujuan mendidik para mahasiswa untuk siap diterjunkan ke masyarakat untuk melayani secara spiritual dengan wawasan oikumenis dan menyatakan "kasih" dalam segala bidang kehidupan (Buku Panduan Fakultas Teologi UKSW, 2004). Oleh karenanya, proses pendidikan difokuskan kepada pembinaan rohani yang pada akhirnya dapat menjadi sarana dalam proses pematangan spiritual dan kesediaan penuh untuk melayani (menolong).

Henri J.M. Noumen (1974) memberikan satu persyaratan utama pelayanan seorang lulusan teologi (pendeta), yaitu "compassion" atau kesediaan mengorbankan diri untuk menolong orang lain baik secara fisik maupun psikis. Dalam perspektif pastoral, William Clebsch dan Charles Jaekle (1964) menam- bahkan persyaratan tersebut dengan kemampuan memberikan kenyamanan, kekuatan, keamanan, dan mengurangi beban orang lain. Dengan demikian, STT sebagai institusi pendidikan bagi pelayan rohani (pendeta) menjadi tempat yang sesuai untuk penelitian tentang spiritualitas dan motif prososial. Mahasiswa STT diarahkan untuk mengembangkan motivasi untuk menolong, mengingat pekerjaan pelayanan yang akan mereka lakukan.

\section{METODE PENELITIAN}

Penelitian ini ditujukan untuk melihat hubungan dua variabel yaitu antara kematangan spiritual dan motif prososial. Populasi sasaran dalam penelitian ini adalah mahasiswa Sekolah Tinggi Teologi di Bandung yang terdiri dari Institut Alkitab Tiranus, Sekolah Tinggi Teologi Bandung, dan Sekolah Tinggi Teologi Baptis. Teknik pengambilan sampel secara purposive sampling, yang mana sampel yang diambil harus memenuhi kriteria tertentu yang telah ditetapkan. Jumlah sampel dalam penelitian ini adalah 300 orang.

Untuk memperoleh data empirik dari variabel penelitian ini, yaitu kematangan spiritual dan motif prososial, maka digunakan alat ukur sebagai berikut: Kuesioner kematangan spiritual dengan mengadaptasikan alat ukut dari Hall $\&$ Tood dari Biola University. Sedangkan kuesioner motif prososial yang disusun berdasarkan konsep Batson.

Validitas dari alat ukur ini menggunakan construct validity, sedangkan pengujian reliabilitasnya menggunakan teknik Alpha Cronbach. Dari hasil uji coba diperoleh bahwa semua item dinyatakan valid dengan nilai validitas berkisar antara 0,405 - 0,793. Berdasarkan pengujian reliabilitas, derajat reliabilitas alat ukur Kematangan Spiritual untuk masingmasing dimensi dan sub dimensi: awareness 0,800 ; unsatable 0,702 ; grandious 0,605 ; realistic acceptance 0,873 . Sedangkan derajat reliabilitas alat ukur Motif Prososial untuk masing-masing aspek: egoism 0,603; kolektivism 0,608 ; principilism 0,734 ; altruism 0,604 . Verdasarkan derajat reliabilitas di atas bisa dilihat bahwa semua dimensi reliabel karena semua berada di atas 0,6.

Data yang diperoleh dari hasil penelitian ini akan dianalisis dengan menggunakan koefisien korelasi kontingensi dan korelasi Pearson. 


\section{HASIL DAN PEMBAHASAN}

Rumus statistik koefisien kontingensi digunakan untuk pengujian hipotesis utama dan rumus statistik koefisien korelasi Pearson digunakan untuk pengujian sub hipotesis. Selanjutnya dilakukan pengujian signifikansi korelasi dengan derajat kepercayaan $95 \%$ atau derajat kesalahan $\alpha=5 \%(0,05)$.

Hasil pengujian hipotesis dengan menggunakan koefisien kontingensi adalah sebagai berikut:

Tabel Korelasi antara Kematangan Spiritual dan Motif Prososial

\begin{tabular}{cccc}
\hline $\mathbf{C}$ & $\mathbf{X}^{2}$ & Tabel C & Keterangan \\
\hline 0,6364 & 204,18 & 27,88 & $\begin{array}{c}\text { Ho ditolak } \\
\mathrm{H}_{1} \text { diterima }\end{array}$ \\
\hline
\end{tabular}

Berdasarkan hasil perhitungan tes $\mathrm{X}^{2}$ diperoleh hasil 204,18 yang lebih besar jika dibandingkan dengan nilai di tabel C (Siegel, 1956) yaitu 27,88 dengan taraf signifikansi 0,001 . Sesuai kriteria pengujian hipotesis yaitu tolak Ho jika $X^{2}>$ nilai tabel $\mathrm{C}(\mathrm{df}=9)$, dengan demikian Ho ditolak dan $\mathrm{H} 1$ diterima. Nilai korelasi (koefisien kontingensi $\mathrm{C}=0,6364$ ) menunjukkan bahwa terdapat hubungan dengan keeratan yang kuat antara kematangan spiritual dan motif prososial pada mahasiswa STT. Artinya dimensi-dimensi di dalam kematangan spiritual saling berhubungan dengan dimensi-dimensi dalam motif prososial.

Berdasarkan hasil analisis, diketahui bahwa dimensi Awareness (self-God relationships awareness/ARG), berhubungan erat dengan motif prososial kolektivism dan prinsiplism. Hal ini dapat dijelaskan bahwa hubungan antar individu serta lingkungan sosialnya tidak terlepas dari hubungan individu dengan Tuhan. Kesadaran tersebut menyentuh aspek kognitif dari motif prososial, dimana individu memiliki persepsi terhadap situasi, nilai sosial, dan perspektif sosial yang menga$\mathrm{cu}$ pada hubungannya dengan Tuhan. Kesadaran akan kehadiran Tuhan dalam setiap situasi dalam hidupnya akan menjadi dasar bagi individu dalam mempersepsikan situasi lingkungan yang membutuhkan pertolongan. Semakin seseorang menyadari kehadiran Tuhan dan menghayati adanya hubungan yang terusmenerus dengan Tuhan maka ia akan memaknakan bahwa Tuhan semakin dekat (intim) dengannya sebagai indikator dari kematangan spiritual. Hal ini berkorelasi dengan hubungan individu dengan orang lain. Semakin sering individu berinteraksi dan berhubungan dengan orang lain, kelompok, organisasi, atau komunitas tertentu maka ia akan memandang hubungan tersebut sebagai kedekatan yang menjadi dasar dari motif prososial yang kolektivism.

"Komunikasi" yang terus menerus dengan Tuhan akan membentuk struktur nilai di dalam diri individu yang mewarnai nilai sosial dan moralitas yang ia anut. "Komunikasi" yang dimaksud misalnya melalui aktivitas berdoa, melalui pemberitaan orang lain, membaca kitab suci, melalui pengalaman (pemikiran dan perasaan) subjektif, penghayatan terhadap kejadian atau situasi tertentu, dan lain-lain. Sedikit banyak individu memperoleh ajaran dan pesan moral yang universal melalui komunikasi tersebut. Dalam hal ini peran agama menjadi cukup penting sebagai fasilitator dalam membangun kesadaran individu atas ajaran moral dari Tuhan. Seperti yang diketahui bahwa semua agama besar mengajarkan pentingnya mengasihi sesama manusia. Oleh karenanya dapat dipahami apabila dimensi ARG ini juga berkaitan dengan motif prososial yang didasari prinsiplism.

Hasil analisis juga menunjukkan dinamika hubungan antara sub dimensi Quality of Relation with God (QRG) dengan motif prososial. Hubungan yang dimaksud mencakup: pertama, hubungan yang kuat antara QRG yang unstable dan motif prososial yang egoism. Kedua, hubungan yang kuat antara QRG yang grandiose dan motif prososial yang egoism. Ketiga, hubungan yang kuat antara QRG yang realistic acceptance dan motif prososial yang altruism.

Pada QRG yang unstable, individu mengalami ketidakstabilan dan ambiguitas dalam hubungan dengan Tuhan yang juga termanifestasi dalam hubungannya dengan individu lain. Individu dalam tingkatan ini sulit membedakan dan mengekspresikan perasaannya, dalam konteks misalnya untuk menyalurkan afek positif dan empati. Demikian juga pada QRG yang grandiose, individu menganggap dirinya lebih baik dari orang lain dalam hubungannya dengan Tuhan. Dengan demikian sulit bagi individu tersebut untuk "mengasihi" orang lain sebagai saluran empati dan afek positif, karena ia sibuk dengan dirinya sendiri sebagai orang yang paling penting di hadapan Tuhan. Oleh karenanya kedua tingkatan tersebut (unstable 
dan grandious) lebih berkaitan dengan motif prososial yang didasari egoism. Sedangkan QRG yang realistic acceptance, bertitik tolak pada hubungan yang realistis dengan Tuhan sebagai figur "pengasih" dan "penolong". Berdasarkan penghayatan atas perlakuan Tuhan terhadap individu dalam kualitas hubungan tersebut, individu mengembangkannya dalam berinteraksi dengan orang lain. "Pengasih" dan "penolong" sebagai bahan yang diadopsi dari pengalaman dan kualitas hubungan dengan Tuhan turut membangun aspek afektif dari motif prososial yaitu elemen empati dan afek positif. Elemen empati yang berkembang pada tingkatan realistic acceptance merupakan hal penting dalam kaitannya dengan motif prososial yang didasari oleh altruism.

Ditinjau dari perbedaan jenis kelamin dalam kaitannya dengan motif prososial, jumlah total derajat sangat kuat dan kuat pada motif prinsiplism, terlihat prosentasi lebih besar pada perempuan $(90 \%)$ dibanding laki-laki $(83,5 \%)$. Peran feminim dalam masyarakat dari perempuan lebih berorientasi pada orang lain dibandingkan dengan laki-laki (Block, 1973, dalam Boehnke, 1989). Menjadi dapat dipahami bahwa perempuan dalam berperilaku prososial lebih mendasarkannya pada kondisi dan kebutuhan orang yang ditolongnya dibandingkan dengan laki-laki yang lebih cenderung mendasarkan tindakan menolongnya pada minat pribadi dan hedonisme (Boehnke, 1989). Sedangkan bila ditinjau dari kematangan spiritual berdasarkan jenis kelamin tidak terdapat perbedaan yang sig-nifikan antara laki-laki dan perempuan.

Kematangan spiritual dan motif prososial menunjukkan perubahan yang signifikan seiring dengan bertambahnya usia. Dimensi awareness (ARG) dari kematangan spiritual misalnya, menunjukkan prosentasi yang bertambah untuk kelompok usia 17 - 20 tahun (46,36\%), $21-25$ tahun (62,79\%), dan $26-30$ tahun $(74,51 \%)$. Demikian juga motif prososial yang egoism terlihat prosentase yang cenderung menurun dari usia 17 - 20 tahun (55\%), $21-25$ tahun $(35,66 \%)$, dan $26-30$ tahun $(27,45 \%)$. Perkembangan spiritual diawali dengan pengaruh formatif dan deformatif sejak individu dilahirkan dan menjalani masa bayi dan anak-anak. Selanjutnya kondisi spiritual tersebut berkembang terus secara dinamis seiring dengan perkembangan psikokognitif dan sosial dalam rentang kehidupan individu (Agus
Cremers, 1995). Berdasarkan uraian singkat ini, dapat dilihat keterlibatan teori-teori perkembangan kepribadian psikoanalisis, kognitif, dan social role taking.

Tahap perkembangan spiritual ke-5 sebagai salah satu proses dinamis dan eksistensial untuk mencari makna dan nilai disebut oleh Fowler (1986) dengan istilah individualreflektif yang biasanya mulai berkembang pada usia 20 tahun atau dewasa awal. Secara kognitif tahap perkembangan formal operasional sudah dilengkapi secara penuh dengan menampilkan ciri-ciri otonomi atas identitas diri, kritis terhadap pandangan dan nilai-nilai serta otoritas konvensional. Akan tetapi pada sisi lain, dalam tahap perkembangan ini individu mulai dibebani dengan tugas-tugas mandiri dan komitmen pribadi serta keterlibatan dalam sistem dan institusi sosial yang lebih luas. Kondisi ini memungkinkan individu untuk mencari dan menyusun secara kritis gambaran tentang Allah yang dapat dipertanggungjawabkan secara pribadi.

Dari data penelitian terlihat prosentase dimensi atau sub dimensi dari kematangan spiritual dan setiap motif prososial yang berimbang pada masing-masing kelompok sampel. Meskipun STTB, STT Baptis, dan IA Tiranus berasal dari denominasi yang berbeda, tetapi menyangkut kematangan spiritual dan motif prososial tidak menunjukkan perbedaan yang signifikan. Hal ini sehubungan dengan latar belakang subjek yang cenderung homogen dari sisi agama yaitu kristen protestan. Oleh karenanya perlakuan dan aktivitas di dalam masing-masing kelompok sampel relatif sama.

\section{SIMPULAN DAN SARAN}

Perubahan pada salah satu dimensi dan subdimensi pada kematangan spiritual maka terjadi perubahan pada motif prososial tertentu. Perbedaan jenis kelamin tidak memberikan variasi dalam pada kematangan spiritual tetapi memberikan variasi pada motif prososial, dimana derajat motif prososial yang didasari prinsiplism terlihat lebih tinggi pada perempuan dibanding laki-laki. Sedangkan pertambahan usia tampaknya menunjukkan perubahan dalam kematangan spiritual dan motif prososial.

Secara umum keeratan hubungan antara kematangan spiritual dan motif prososial masih perlu diuji pada sampel yang lebih luas dan 
heterogen. Hal ini sehubungan dengan konsep spiritual yang sering kali dikaburkan oleh konsep teologi sehingga perbedaan agama menjadi faktor yang layak diperhatikan. Penelitian kematangan spiritual dan motif prososial yang menyangkut pengalaman pribadi individu dalam hubungannya dengan Tuhan serta melibatkan proses intrapsikis yang mendalam maka disarankan pengukuran yang lebih berhati-hati dengan menggunakan interviu serta observasi atau metode kualitatif.

Mengingat tindakan prososial yang didasari oleh motif prososial, terutama yang didasari prinsiplism dan altruism dapat memperkokoh keharmonisan hubungan antara si penolong dan si penerima bantuan, maka perlu upaya-upaya mempertahankan atau meningkatkannya terutama melalui pematangan spiritual. Upaya pematangan spiritual ini dapat diberikan melalui diskusi-diskusi, pelatihan-pelatihan, dakwah atau khotbah, dan media lain.

\section{DAFTAR PUSTAKA}

Baltes, P.B., Reese, H.W., \& Nesselroade, J.R., Introduction to Research Methods : LifeSpan Developmental Psychology, Lawrence Erlbraum Associate Inc., 1988.

Batson CD. 1998. Altruism and prosocial behavior. In The Handbook of Social Psychology, ed. DT Gilbert, ST Fiske, G Lindzey, vol. 2, pp. 282-316. New York: McGraw-Hill. 4th ed.

Batson, C. D., Sympson, S. C., Hindman, J. L., Decruz, P., Todd, R. M., Weeks, J. L., Jennings, G. \& Burris, C. T. (1996). "I've Been There, Too": Effect on Empathy of Prior Experience with a Need. Personality and Social Psychology Bulletin, 22(5), 474-483.

Batson, C.D., 1994. Prosocial Motivation: Why Do We Help Others? In Tesser, N. (Ed), 1994. Advanced Social Psychology (Hal. 333 - 381). Boston : McGraw-Hill. Batson, C.D., Shaw, L.L. 1991. Evidence for Altruism: Toward a Pluralism of Prosocial Motives. In Journal of Psychological Inquiry, Vol. 2. 1991. Hal. 107 122.

Brokaw, B. F. \& Edwards, K. J. (1994). The relationship of God image to the level of object relations development. Journal of Psychology and Theology, 22, 352-371.
Carter, J. D., \& Barnhurst, L. F. (1986, October). Maturity, Intimacy and Spirituality. Paper presented at the meeting of the Christian Association for Psychological Studies-Eastern Region, Speculator, NY.

Clair, M.St., Object Relation and Self Psychology. Second Edition, Brook/Cole Publishing Company, USA., 1996.

Crapps, R.W., Dialog Psikologi dan Agama, Kanisius, 1993.

Cremers Agus., Tahap-tahap Perkembangan Kepercayaan menurut James W. Fowler : Sebuah Gagasan Baru dalam Psikologi Agama, Kanisius, 1995.

Clebsch, William A., and Charles R. Jackle. Pastoral Care in Historical Perspective. New York: Harper and Row, Publishers/Harper Torchbooks, 1964.

Fowler, J.W., Faith Development and Pastoral Care, Philadelphia: Fortes Press, 1986.

Fuhrmann, Barbara Schneider., Adolescence, Adolescent, Second Edition. A Division of Scott, Foresman and Company, Illinois, 1990.

Hall, W.T., \& Edward, J.K., The initial Development of Factor Analysis of the Spiritual Assessment Inventory, Journal of Psychology and Theology, Vol. 24, No 3, 233 - 245., 1996.

Hall, T.W. \& Edwards, K.J., The Spiritual Assessment inventory: A theistic model and measure for assessing spiritual development. Journal for the Scientific Study of Religion, 41(2), 341-357., 2002.

Harvard Education Review., reprinted No. 13, Stage Theories of Cognitive and Moral Development: Criticisms and Application, 1978.

Havighurst, R. J. 1984. History of Developmental Psychology. Lawrence Erlbaum Associates.

Hill, P., \& Hood, R. (Eds.)., Measures of Religiouslity. Birmingham, AL: Religious Education Press, 1999.

Maslow, A. Religions, Values and Peak-Experiences NY: Penguin Books, 1964, 1976.

Harmondsworth, Eng: Penguin, 1964, 1976, 1978, 1986.

Noumen, M.J. Henri and Gaffney J. Walter: Aging. The Fulfillment of life. New York: Garden City 1974, 156 s. 
Rakhmat, J. (2003). Psikologi Agama: Sebuah Pengantar. Mizan Media Utama, Bandung.

Saucy, R. (1993). The Case for Progressive Dispensationalism. Central Baptist Theological Seminary.

Saroglou, V. (2002). Religion and the five factors of personality: A meta-analytic review. Personality and Individual Differences, Journal for the Scientific Study of Religion, vol. 32, 15-25.
Staub, E. (1970). A child in Distress: The effects of focusing responsibility on children on their attempts to help. Developmental Psychology, 2, 152-153.

Zohar, D., \& Marshall, I., SQ : Spiritual Intelligence, The Ultimate Intelligence, Bloomsbury Publishing, Great Britain, 2000.

http://www.kompas.com/kompas-cetak/0501/ 28/opini/1498098.htm

http://www.kompas.com/kompas-cetak/0411/ 29/daerah/1404387.htm 